\title{
Editorial on the first issue of the new journal "Leadership, Education, Personality: An Interdisciplinary Journal"
}

\author{
Editorial zur ersten Ausgabe des neuen Journals „Leadership, Education, Personality: An \\ Interdisciplinary Journal“"
}

\author{
Werner G. Faix ${ }^{1}$
}

(c) The Author(s) 2019

When the Greek philosopher Heraclitus stated around 500 BC that "nothing is as constant as change", he could hardly have guessed how true this statement would still be 2500 years later. As mankind is facing the greatest challenges today:

- To implement human rights for all people.

- To sustainably slow down the still undamped, exponential growth of humanity.

- To realize sustainability, i.e. stop climate change, regulate the consumption of resources, stop the catastrophic extinction of species, and stop deforestation, reverse marine and air pollution, stop soil poisoning, etc.

- To shape digitalization with super computers, quantum computers, artificial intelligence, Internet of Things, Big Data, Virtual and Augmented Reality, 3D printing, Blockchain, Bitcoin, and robotics in the spirit of humanism.

- To actively attend the use of biotechnology and nanotechnology in terms of ethical aspects, such as the possibilities of CRISPR/Cas9.

- To cope with the rapidly increasing complexity.

- To develop an economy and corresponding systems that not only meet people's basic needs, but also their social, intellectual and spiritual needs.

- To redefine the United Nations in a global world and at the same time realize the subsidiarity of nations and population groups.

- To enable all people to live in dignity in peace, freedom and self-determination.

Werner G. Faix

Faix@steinbeis-sibe.de

1 School of International Business and Entrepreneurship (SIBE) der Steinbeis-Hochschule Berlin, Herrenberg, Germany
In order to handle these challenges and to shape the future of humanity, many actors in societies, politics, science, education, business, religions, etc. with the appropriate knowledge, qualifications, skills, performance, and personality are needed. Personalities who are able and willing to assume leadership for themselves and for human communities are needed. Management tasks can be left to self-learning algorithms in the future!

$\mathrm{We}^{3}$ define leadership as follows: to lead oneself and human communities ${ }^{4}$ ethically, sustainably, innovatively, creatively and agilely into the future within open, complex situations under unclear and dynamic conditions.

Ethical and sustainable means to shape the survival, the performance and the positive development of the organization from which one emerged and with preservation of nature.

Innovative, creative and agile means leading an organization to be enabled and open to shape transformation processes with the ongoing goal of producing innovations, including disruptive and radical ones, and making them reality.

Leading into the future means shaping the future and, in a complex and changing world, while having clear ideas of the future and the goals derived from them.

In order to achieve these goals, a (r)evolution of the entire educational system is required. Plato already explained in the Politeia that it is not of decisive importance for people in state leadership that they are educated in negotiation, warfare, urban development, etc., but that they possess personality.

\footnotetext{
${ }^{3}$ For the School of International Business and Entrepreneurship (SIBE) at Steinbeis University Berlin, the terms leadership, education and personality have been central to our research and teaching for many years.

${ }^{4}$ Human communities: organizations, companies, research groups, political parties, etc. and their sub-communities.
} 
In schools with classes of up to 30 pupils, knowledge must be learned by heart and in universities with so-called bulimia "courses of study", the graduates are not able to compete with future digital and quantum systems, let alone to be able to take on leading and shaping tasks. The objective of university education is to enable the formation of self-determined, responsible personalities in the unity of research and teaching, and to revitalize humanistic educational content as an end in itself to the human personality and its contribution to society through non-isolated objectives. Or, in other words, to provide a course of study in which students are educated to generate benefits in their respective partnership (university, company, organization, etc.) by turning good ideas (their own or others') into sustainable and value-creating reality and thus systematically developing performance and leadership competencies and making clear progress in their development towards a creative personality. In addition, students should have the skills to develop systematically and independently even after graduation. The same applies to personnel and management development in companies and organizations.

Objective of the journal "Leadership. Education. Personality: An Interdisciplinary Journal" is to take up all these aspects in an interdisciplinary way and to discuss and further develop the complex of topics with scientific contributions from science and practice.

Editor-in-Chief

Prof. Dr. Dr. h.c. Werner G. Faix 
Als der griechische Philosoph Heraklit ca. 500 v. Chr. konstatierte "Nichts ist so stetig wie der Wandel", konnte er kaum ahnen, wie wahr diese Aussage auch 2.500 Jahre später noch sein sollte. Denn die Menschheit steht heute vor den größten Herausforderungen:

- Sie muss die Menschenrechte für alle Menschen verwirklichen.

- Sie muss das nach wie vor ungebremste, exponentielle Wachstum der Menschheit nachhaltig bremsen.

- Sie muss Nachhaltigkeit Wirklichkeit werden lassen, d.h. den Klimawandel stoppen, den Ressourcenverbrauch regulieren, das katastrophale Artensterben stoppen, die Abholzung der Wälder stoppen, die Verschmutzung der Meere und der Luft rückgängig machen, die Vergiftung der Böden stoppen etc.

- Sie muss die Digitalisierung mit Super-Computern, Quanten-Computern, Künstlicher Intelligenz, Internet of Things, Big Data, Virtual und Augmented Reality, 3D-Druck, Blockchain und Bitcoin sowie Robotik aktiv im Geiste des Humanismus gestalten.

- Sie muss die Verwendung von Bio- und Nanotechnologie hinsichtlich ethischer Aspekte aktiv gestalten, wie etwa die Möglichkeiten von CRISPR/Cas9.

- Sie muss mit der stark zunehmenden Komplexität zurechtkommen.

- Sie muss eine Wirtschaft und entsprechende Systeme entwickeln, die nicht nur den Grundbedürfnissen der Menschen gerecht werden, sondern auch den sozialen, geistigen und spirituellen Bedürfnissen.

- Sie muss in einer globalen Welt die Vereinten Nationen neu definieren und gleichzeitig Subsidiarität der Nationen und Bevölkerungsgruppen verwirklichen.

- Sie muss für alle Menschen ein menschenwürdiges Leben in Frieden, Freiheit und Selbstbestimmtheit ermöglichen.

Um diese Herausforderungen zu bewältigen und um die Zukunft der Menschheit zu gestalten, bedarf es vieler Akteure in den Gesellschaften, der Politik, der Wissenschaft, der Bildung, der Wirtschaft, den Religionen etc. mit entsprechendem Wissen, mit Qualifikationen, mit Kompetenzen, mit Performanz und eben mit Persönlichkeit. Es bedarf Persönlichkeiten, die in der Lage und willens sind, Leadership für sich und für menschliche Gemeinschaften zu übernehmen. Denn die Aufgaben des Managements können in Zukunft getrost selbstlernenden Algorithmen überlassen werden!

Leadership definieren wir ${ }^{1}$ folgendermaßen: Sich selbst und menschliche Gemeinschaften ${ }^{2}$ in offenen, komplexen Situationen unter nicht klar definierten und dynamischen Rahmenbedingungen mit Persönlichkeit ethisch, nachhaltig, innovativ, kreativ und agil in die Zukunft zu führen.
Ethisch und nachhaltig bedeutet, das Überleben, die Performanz und die positive Entwicklung der Organisation zu gestalten, mit Nutzen-Stiftung für die Sozietät aus der man hervorgegangen ist und unter Bewahrung der Natur.

Innovativ, kreativ und agil bedeutet, eine Organisation so zu führen, dass sie in der Lage und offen ist, Transformationsprozesse zu gestalten, mit dem permanenten Ziel, Innovationen—auch disruptive und radikale—-hervorzubringen und agil Wirklichkeit werden zu lassen.

In die Zukunft führen bedeutet, die Zukunft zu gestalten und setzt in einer sich komplex verändernden Welt voraus, klare Vorstellungen von der Zukunft und daraus abgeleitete Ziele zu haben.

Um diese Ziele zu erreichen, bedarf es einer (R)Evolution des gesamten Bildungswesens. Schon Platon hat in der Politeia ausgeführt, dass es für Menschen in der Staatsführung nicht von entscheidender Bedeutung ist, dass sie in Verhandlungsführung, Kriegsführung, Städtebau etc. gebildet sind, sondern dass sie Persönlichkeit besitzen.

Mit Schulen in deren Klassen mit bis zu 30 Schülern Wissen auswendig gelernt werden muss, mit Hochschulen an denen sogenannte Bulimie-"Studiengänge" stattfinden, können die Absolventinnen und Absolventen den digitalen bzw. Quanten-Systemen der Zukunft nicht ansatzweise das Wasser reichen, geschweige denn führen und gestalten. Die Zielsetzung von universitärer Bildung ist, in Einheit von Forschung und Lehre, die Bildung von selbstbestimmten, verantwortungsbewussten Persönlichkeiten zu ermöglichen und die humanistischen Bildungsinhalte als Selbstzweck zur menschlichen Persönlichkeit, sowie ihren Beitrag zur Gesellschaft über nicht isolierte Zielvorstellungen zu revitalisieren. Oder anders formuliert, Studierenden ein Studium zu ermöglichen, in dem sie sich bilden, sodass sie in der Lage sind, in ihrer jeweiligen Sozietät (Universität, Unternehmen, Organisation etc.) Nutzen zu stiften, indem sie gute Ideen (eigene oder fremde) nachhaltige und wertschöpfende Wirklichkeit werden lassen und damit systematisch Performanz- und Leadership-Kompetenzen entwickeln und in ihrer Entwicklung zu einer schöpferischen Persönlichkeit einen deutlichen Fortschritt erzielen. Darüber hinaus sollten die Studierenden die Kompetenzen haben, sich systematisch und selbstständig auch nach dem Studium weiterzuentwickeln. Analoges gilt für die Personal- und Führungskräfte-Entwicklung in den Unternehmen und Organisationen.

Zielsetzung des Journals "Leadership. Education. Personality: An Interdisciplinary Journal" ist es, all die genannten Aspekte in interdisziplinärer Weise aufzugreifen und mit

\footnotetext{
${ }^{1}$ Für die School of International Business and Entrepreneurship (SIBE) der Steinbeis-Hochschule Berlin sind die Begriffe Führung (Leadership), Bildung (Education) und Persönlichkeit (Personality) seit vielen Jahren zentraler Punkt unserer Forschung und Lehre.

2 Menschliche Gemeinschaften: Organisationen, Unternehmen, Forschungsgruppen, Parteien, etc. und deren Teilgemeinschaften.
} 
wissenschaftlichen Beiträgen aus Wissenschaft und Praxis den Themenkomplex zu diskutieren und weiterzuentwickeln.

\section{Editor-in-Chief}

Prof. Dr. Dr. h.c. Werner G. Faix
Open Access This article is distributed under the terms of the Creative Commons Attribution 4.0 International License (http://creativeco mmons.org/licenses/by/4.0/), which permits unrestricted use, distribution, and reproduction in any medium, provided you give appropriate credit to the original author(s) and the source, provide a link to the Creative Commons license, and indicate if changes were made. 